\title{
TRANSLATING LEXICAL COLLOCATIONS IN JOURNALISTIC TEXTS: THE CASE OF ENGLISH AND MACEDONIAN
}

\author{
Silvana Neškovska \\ St. Kliment Ohridski University, Bitola \\ silvana.neskovska@uklo.edu.mk
}

Collocations play a vital role in language by making it sound more natural, precise and interesting. Hence, handling collocations with special care and vigilance should be high on translators' agendas. The aim of this study was to determine how Macedonian translators fare in rendering lexical collocations from Macedonian into English in journalistic texts. The questions addressed were the following: Are lexical collocations correctly rendered from Macedonian into English?; Are the same types of lexical collocations preserved in the translated texts?; What are the high-frequency and the low-frequency lexical collocations in the original and translated texts?; What translation strategies are employed in rendering lexical collocations? The results of the study indicate that there is a high level of awareness on the part of translators when it comes to rendering collocations correctly. Surprisingly, there were also more similarities than differences in the internal structure of TL and SL lexical collocations, with the most prominent types in both languages being: adjective + noun and verb + noun. Finally, literal translation was the most frequently employed translation strategy, yielding mostly positive results in all likelihood because all of the analysed collocations were used in the domain of politics and were cross-linguistic.

Keywords: lexical collocations, news articles, translation strategies 


\title{
ЛЕКСИЧКИТЕ КОЛОКАЦИИ ВО ПРЕВОДИТЕ ОД МАКЕДОНСКИ НА АНГЛИСКИ ВО НОВИНАРСКИТЕ ТЕКСТОВИ
}

\author{
Силвана Нешковска \\ Универзитет „Св. Климент Охридски“, Битола \\ silvana.neskovska@uklo.edu.mk
}

Колокациите имаат клучна улога во јазикот, бидејќи придонесуваат тој да звучи поприродно, попрецизно и поинтересно. Оттука, еден од главните приоритети на преведувачите треба да биде точното и правилно пренесување на колокациите од јазикот извор во јазикот цел. Целта на ова истражување е да се одреди како се справуваат македонските преведувачи со преведувањето лексички колокации од македонски на англиски во новинарски текстови. Истражувањето беше во насока да одговори на следниве прашања: Дали лексичките колокации се преведуваат точно од македонски на англиски? Дали истите видови лексички колокации се среќаваат во двата јазика? Кои се најчесто и најретко користените лексички колокации во оригиналите и во преведените текстови? Кои преведувачки стратегии се употребуваат за преведување на лексичките колокации? Резултатите од истражувањето покажуваат дека постои високо ново на свесност кај преведувачите при преведувањето на лексичките колокации. Исто така, изненадува фактот дека беа забележани повеќе сличности отколку разлики во внатрешната структура на лексичките колокации во јазикот извор и во јазикот цел, и дека и во двата јазика најчесто користени беа следниве колокации: придавка + именка и глагол + именка. Буквалниот превод беше најчесто користената стратегија за преведување, која резултираше со точен превод, најверојатно бидејќ с сите анализирани колокации се употребуваат во доменот на политиката и се среќаваат во повеќето светски јазици.

Клучни зборови: лексички колокации, колумни во весници, стратегии за преведување 


\section{Introduction}

Collocations are word combinations that always recur in a particular language and form an essential part of the language. They make the language sound more natural and interesting. Baker (1992: 47) discusses the importance of collocations in language and depicts them as "the tendency of words to co-occur regularly in a given language". She also points out that new collocations are created all the time and that they can be used as "a backdrop against which new images and new meanings can be invoked" (1992: 52). Nevertheless, collocations sometimes do present real challenges for both non-native learners of English as well as for translators, who are expected to "juggle" effortlessly with collocations from both their mother tongue and the foreign language. The arbitrary nature of collocations, i.e. the fact that there are no hard and fast rules to be strictly followed in their creation, is one of the main obstacles (e.g. one can bend rules but rules cannot be unbendable, as rules are inflexible). In addition, collocations are language specific, i.e. they reflect completely distinct cultural and social realities of different language communities. This means that there are noticeable differences in the collocational patterns of different languages (for instance, in English students do homework, but in Macedonian they write homework).

In this study an attempt is made to shed light on the translation of lexical collocations in journalistic texts from Macedonian into English by translators whose mother tongue is Macedonian. This option has been selected as it is deemed far more challenging to translate from one's mother tongue into one's foreign language (and, hence even less advisable according to Newmark (1981)) than vice versa. For the purposes of this study, a corpus of newspaper articles originally written in Macedonian and their translation into English has been compiled.

Also, given that English and Macedonian are two completely distinct languages, differences in their collocational patterns are deemed inevitable, and, therefore, worth exploring. Furthermore, considering the fact that the translation of newspaper articles intended for daily newspapers is normally done at a very fast pace and under serious time constraints, translators must render their translations and deal with the collocations in them, very quickly, which, in turn, significantly increases the chances of producing erroneous or non-existent collocations in the target language.

The study seeks to answer the following questions: "Are the lexical collocations in the journalistic texts translated correctly from Macedonian into English?"; "Is there any overlapping in the internal structure of the lexical collocations in both languages?"; "What are the high-frequency and low-frequency lexical collocations in both the original and translated texts?" and "What translation strategies have the translators employed in rendering the collocations from Macedonian into English?".

\section{Theoretical overview}

\subsection{Collocations and their main features}


Collocations present a great chunk of every language and are constantly used in both written and oral discourse. They are normally defined as "arbitrary recurrent word combinations" (Benson, Benson and Ilson 1986, 1997), i.e. "words that are associated to each other and co-occur repeatedly in a prefabricated chunk" (Shraideh and Mahadin 2015). Studies on collocations in English show that all collocations share certain distinctive features (Baker 1992). Thus, for instance, each collocation is deemed to have its own collocational range. Some collocations have a wider collocational range (e.g. to run a company/business/course); whereas, some have a more restricted one (e.g. to shrug mainly collocates with shoulders). Nevertheless, the collocational range of a word is by no means fixed - words constantly attract new collocations, which, in turn, either become a standard part of the language or become extinct shortly after they are introduced. The arbitrary nature of collocations and the fact that collocations are independent of meaning (e.g. unblemished, spotless, flawless, immaculate are all synonymous, but do not combine with the same set of nouns) is another distinctive feature of collocations.

Native speakers of English generally acquire and use collocations instinctively, quickly and spontaneously. Conversely, non-native speakers tend to produce inappropriate collocations very often, mainly, because the English words are not stored in their memory linked with other words, but in isolation (Shraideh and Mahadin 2015). Additionally, non-native speakers of English experience difficulties with English collocations because the collocational patterns that exist in English are not universal. On the contrary, collocations are usually culture-specific (Shraideh and Mahadin 2015). Despite their culture-specific nature, great many collocations are actually cross-linguistic, meaning a particular collocation used in one language has a counterpart in the other languages as well (Yamashita and Jiang 2010).

A lot of the research efforts have also been directed at investigating the internal structure of collocations. Sinclair (1991) noted that all collocations consist of a node - the main word in the collocation pattern, and collocates - the words that come either to the right or to the left of the node. Analyzing the structure of collocations, Benson, Benson and Ilson $(1986,1997)$ distinguish between grammatical and lexical collocation. Grammatical collocations include a content word and a preposition or a grammatical structure, and can be further subdivided into eight major types: 1. noun + preposition (e.g. hostility between); 2 . noun + to + infinitive (e.g. pleasure to do it); 3 . noun + that + clause (e.g. an oath that he would do his duty); 4. preposition + noun (e.g. at anchor); 5. adjective + preposition (e.g. angry at everyone); 6 . adjective + to + infinitive (e.g. it was necessary for him to work); 7. adjective + that + clause (e.g. it was imperative that I be there); 8. nineteen English verb patterns. Lexical collocations are composed of content words only and include the following subtypes: 1 . verb + noun/pronoun or prepositional phrase (e.g. set a record); 2. verb + noun (e.g. squander a fortune); 3 . adjective + noun (e.g. pitched battle); 4. noun + verb (of action) (e.g. blizzards rage); 5 . noun + of + noun (e.g. a bouquet of flowers); 6. adverb + adjective (e.g. strictly accurate), and 7. verb + adverb (e.g. apologize humbly).

Other researchers have investigated the internal structure of collocations and have proposed their own classifications of collocations. Thus, according to Hill 
(2000) there are two categories of collocations: short and long collocations. The former normally consist of two or three elements: 1. adjective + noun (e.g. huge profit); 2 . noun + noun ( $a$ e.g. pocket calculator); 3 . verb + adjective + noun (e.g. learn a foreign language); 4. verb + adverb (e.g. live dangerously); 5. adverb + verb (e.g. alf understand); 6. adverb + adjective (e.g. completely soaked); 7. verb + preposition + noun (e.g. speak through an interpreter), etc. The latter are made up of more than three elements, for instance, adverb + verb + adjective + noun + preposition + noun (e.g. seriously affect the political situation in Northern Ireland). McIntosh et al. (2009) adopted another approach to categorizing collocations based on the main element in the collocation and recognized: noun collocations, verb collocations, and adjective collocations. Noun collocations include: adjective + noun (e.g. bright light), quantifier + noun (e.g. a beam of light), verb + noun (e.g. cast light), noun + verb (e.g. light gleams), noun + noun (e.g. a light source), preposition + noun (e.g. by the light of the moon), and noun + preposition (e.g. the light from the window). Verb collocations comprise: adverb + verb (e.g. choose carefully), verb + verb (e.g. be free to choose), and verb + preposition (e.g. choose between two things). Finally, the following word combinations are labelled as adjective collocations: verb + adjective (e.g. declare smth. safe), adverb + adjective (e.g. perfectly safe), and adjective + preposition (e.g. safe from attack).

Macedonian grammar books do not dwell on the issue of collocations in particular. The linguistic phenomenon of lexical collocations is, however, touched upon in some rather recent research papers of few contemporary researchers who mainly focus on the verb collocations in Macedonian (Karapejovski, 2011; Janusheva, 2018 , etc.).

\subsection{Translation of collocations}

Rendering collocations from the source (SL) to the target language (TL) has proven to be an area of great difficulty for translators. It has been widely acknowledged that a translator "will be 'caught' every time, not by his vocabulary, but by his unacceptable or improbable collocations" (Newmark 1981; Fillmore 1985) (in Shammas 2013). One of the most frequently mentioned reasons is the arbitrary nature of collocations, i.e. the fact that their formation is not guided by any rules in a principled way. This means that it is not sufficient for translators to translate only the components of collocations; it is much more important to render their semantic content as well as their cultural traits. In addition, translators are known sometimes to get so absorbed in the source text that they end up producing, almost completely unconsciously, the oddest collocations in the target language (Barnwell 1980). Baker (1992) warns that a translator can easily misinterpret a collocation in the source text due to interference from his/her native language.

Naturally, detecting collocations in the original text is the first vital step that translators take (Al-Rawi 1994, in Mahdi and Yasin 2015). Hatim \& Mason (1990) and Newmark (1981) also point out that translators' primary goal should always be the naturalness of the language they use in the target text. In line with this is Baker's 
(1992) contention a good method for detecting and removing unnatural collocations from the target text is to put the translation aside for a brief interval of time, and then reread it from a native speaker's perspective (provided the translator is translating in his/her mother tongue).

Well-versed translators make use of a range of different translation strategies in transferring linguistic material from SL into TL. The same strategies apply to rendering collocations too. Vinay \& Darbelnet (1995) identify two general categories: a) direct translation strategies which include: borrowing, calque, and literal translation; and b) oblique translation, which consists of modulation, transposition, equivalence, and adaptation. Borrowing "involves the transference of the ST word into the TT"; whereas calque occurs when "a language borrows an expression from another, but then translates literally each of its elements". Literal translation is "a word-for-word rendering. Transposition "concerns grammatical shift such as word class changes"; modulation entails "a variation of the form of the message, obtained by a change in the point of view"; equivalence refers to cases where languages describe the same situation by means of different stylistic or structural means", and adaptation involves "changing the cultural reference when a situation in the source culture does not exist in the target culture".

\section{Research methodology}

The aim of this study was to investigate the process of translating Macedonian lexical collocations into English. For the purposes of this study, a corpus of 14 newspaper articles was compiled of about $400-600$ words each -7 articles were originally written in Macedonian and the other 7 were their translations in English. All of the articles were published in the Macedonian daily newspaper Nezavisen. All of the selected articles referred to topics related to politics and political events, and were released within a relatively short time span (the last week of June, 2018, and the first week of July, 2018) (see Appendix). The initial stage of the research entailed a careful perusal of the Macedonian articles and detection of the lexical collocations used in them. This process was mainly based on the different classifications of collocations discussed in the previous section (Benson, Benson and Ilson 1986, 1997; Hill 2000, and McIntosh et al. 2009), since, to the best of our knowledge, no similar classification of collocations has been proposed in Macedonian so far. Subsequently, the corresponding translation equivalents of the Macedonian collocation were pinned down in the English translation. A contrastive analysis of the collocations from the original texts and their respective counterparts in the translated texts was then carried out, in order to ascertain whether these were true translation equivalents.

The selected SL and TL collocations were then analyzed from the perspective of their specific syntactic patterns, i.e. internal structure, and were, consequently, classified into different subtypes, the intention being to ascertain whether there was any overlapping in the syntactic structure of the corresponding SL and TL collocations. The analysis was quantitatively oriented in that it also sought to establish the high- 
frequency and the low-frequency collocations in both the original and translated articles as well.

Eventually, in the last stage of the research, the focus was placed on determining the translation strategies translators employed in rendering the analysed collocations.

\section{Results}

The first research stage as mentioned previously was directed at detecting the lexical collocations (henceforth LC) in the original texts and their translation equivalents in the translated texts, as well as at ascertaining if the proposed collocations in the translated texts were, in fact, correct renderings of the original LC. In that respect, $185 \mathrm{LC}$ in total were extracted from the 7 analyzed Macedonian newspaper articles. The number of their corresponding LC in the 7 translated texts in English was somewhat smaller, i.e. $168 \mathrm{LC}$, though (see Figure 1). This was due to the fact that some of the Macedonian LC were rendered as single words in English (13 out

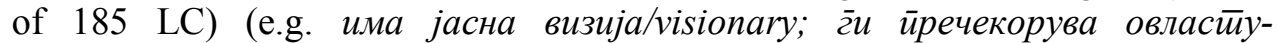
вања/overreaches; йорреgена йозииија/subordination) and some were not rendered at all (4 out of 185) (e.g. in the sentence „Во иоослеяно време се чини на иолийичкайа сцена нема йойрагично-комична фигура оо онаа на иррейсе-

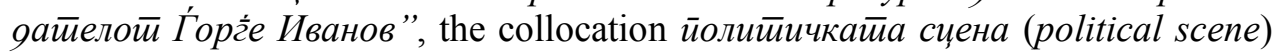
was completely omitted in the translation and the resultant sentence was: "Lately it seems that there is no bigger tragic-comic political figure than President Ivanov").

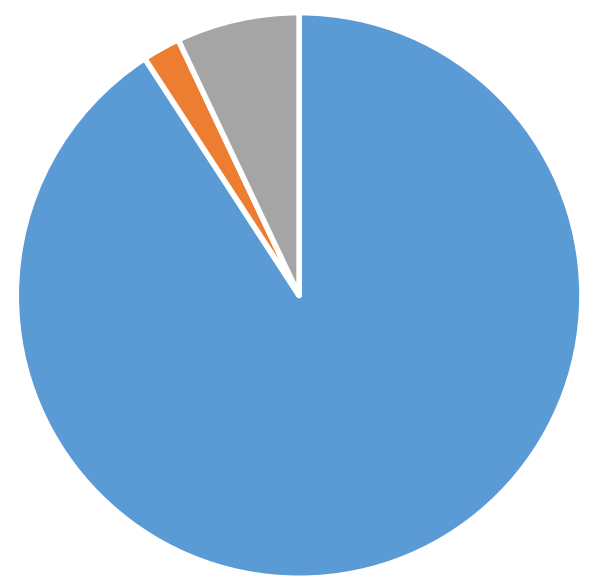

- Lexical collocations $\quad$ Omitted collocations $\quad$ Single words

Figure 1. The rendering of the Macedonian LC into English 
Most of the Macedonian LC were rendered correctly in English. Two online collocation dictionaries were consulted to confirm the correctness of the collocations in the translated texts ${ }^{1}$. In fact, merely 21 collocations out of 168 were found to be inaccurately rendered. The analysis of the erroneous renderings showed that, the mistakes were not made due to lack of adequate translation equivalents in English. On the contrary, the mistranslations appeared as a result of: word for word translation; false friends, overly liberal/free translation and atypical source language collocations (see Figure 2).

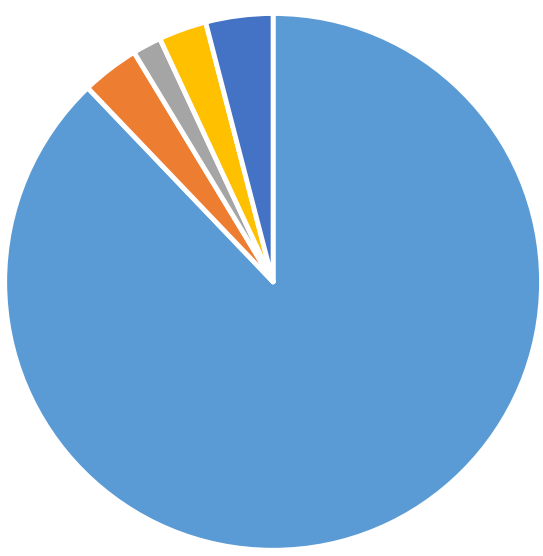

- correctly rendered colloctions in English

- word for word translation

- false friends

atypical colloctions

- overly free translations

Figure 2. Correctly vs. incorrectly rendered LC in English

Word for word translation of collocations (6 out of 21 mistranslations) can be attributed to the translators' mother tongue interference. In fact, being engrossed in the translation process and under the influence of their native language, the translators, most probably, unconsciously following closely the collocational pattern of the original collocations ended up producing non-existent collocations in English. Thus, for instance, the collocation фабрички грешка (adjective + noun), whose English counterpart is manufacturing defect, was translated word for word as fac-

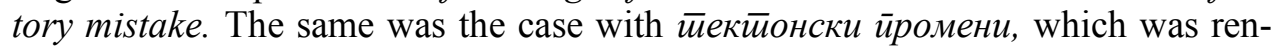
dered as tectonic changes instead of tectonic shifts. False friends (3 out of $21 \mathrm{LC}$ ), words that sound similar in both the source and target language but have different meanings, were also one of the reasons for producing erroneous collocations in the

\footnotetext{
${ }^{1}$ Online Oxford Collocation Dictionary (http://www.freecollocation.com/); Free Online Collocation Dictionary (https://prowritingaid.com/Free-Online-Collocations-Dictionary.aspx).
} 
TL. Thus, for instance, the collocation евенимуално членсииво in the TL was rendered as eventual membership instead of likely/possible membership.

In some cases, the mistranslation appeared as a result of overly liberal translation (7 out of 21 LC). In fact, in these cases the translators have selected collocations from the target language whose semantic content only partly overlaps with the semantic content of the original collocations (e.g. воэи оискусија was rendered as to be engaged in a discussion instead of to lead the discussion; го крши Усіи аво $\bar{u}$ was translated as to ignore the Constitution instead of to disobey the Constitution; фолгоо влаяеење was translated as long coalition instead of long rule, etc.). Finally, there were a few instances in which the miscues were due to atypical collocations used in the Macedonian corpus (5 out of 21 LC), which, naturally, led to producing even more awkward translation equivalents in English (e.g. pеализира ириорииетии/realize priorities instead of set priorities; г̈ласа gеклараиија/to vote a declaration instead of to issue/make a declaration). Interestingly, in this context, it is worth mentioning that a few of the atypical Macedonian LC were, in fact,

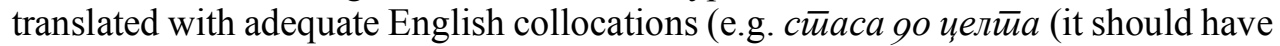
been jа йосииигнува иелима) was rendered as reach the goal, which fitted perfectly into the given context).

In the next phase, the research was focused on classifying the LC from both the original texts and translated texts into different subtypes according to their syntactic structure. In that respect, two predominant subtypes or high-frequency LC in both the original and translated texts emerged: 1 . adjective + noun; and, 2 . verb + noun (see Figure 3).

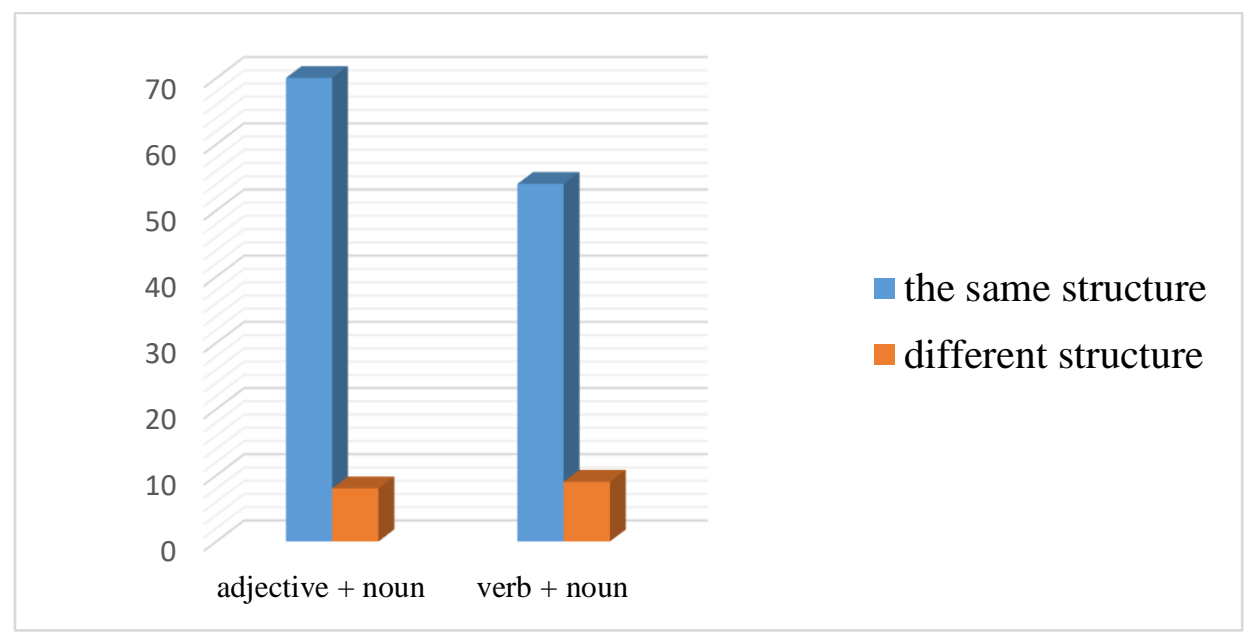

Figure 3. The syntactic structure of the high-frequency LC

More precisely, the greatest number of identified LC were realized as adjective + noun (78 out of $168 \mathrm{LC}$ ) in the Macedonian corpus (e.g. суяски реформи/judicial reforms; фийломайска мрежа/diplomatic network; крајна иел/ultimate goal; ииотиален неусиет/total failure). A significant number of these collocations com- 
prised more than two or more adjectives used attributively before the noun functioning as a node. Thus, for instance, there were instances of 2 adjectives + noun (е.g. ирреявремени йарламенйарни избори/еarly parliamentary election; значаен истиориски настиан/important historical event); 3 adjectives + noun (e.g. куличурна, иивилизациска и оишиеесиввена револучија/cultural, civilization and social revolution), and 4 adjectives + noun (e.g. најг̃олем, иолиииички, економски и воен сојуз/the largest political, economic and military alliance).

Almost all of the English translation equivalents of the adjective + noun collocational patterning were of the same type (see Figure 3). There were just a few instances when they were rendered differently, i.e. belonged to another collocation subtype ( 8 out of $78 \mathrm{LC}$ ) (е.g. иелосно иніиег̄pирање (adjective + noun)/to integrate fully into (verb + adverb + preposition); йовисок жсивоиен сиианоаро (adjective + adjective + noun)/higher standard of living (adjective + noun + of + noun), фецениски криминал (adjective + noun)/decades of crime (noun + of + noun) etc.). The verb + noun patterning was also very frequent (63 out of $168 \mathrm{LC}$ ) in the Macedonian corpus of newspaper articles. In this collocational patterning, the verb functions as a predicator and the noun that follows it as its object (e.g. $\overline{2} u$ гууби изборите $/$ to lose the election; зајакнува йозиции /to strengthen the positions, нанесува шиметии/to inflict damage). In the verb + noun patterning, the noun was frequently modified with an adjective resulting in the following collocational patterning verb + adjective + noun (e.g. ооржува ообри ояноси/to maintain good

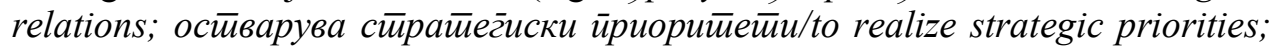
има еянакво ирраво/to have an equal right). Just as in the case of adjective + noun collocations, only few of the noun + verb collocations were rendered in English with collocations with a different syntactic structures (9 out of 63 LC) (see Figure 3) (e.g. зайочнува йрег̄овори/the start of negotiation (noun + of + noun); qоби иооярика /with the support of (Preposition + Noun + Preposition); чувсиивува замор/to be tired of (verb + adjective + preposition); ирави голем ирияонес (verb + adjective + noun)/to contribute to (verb + preposition), etc.).

The presence of the other types of LC in the Macedonian, and, consequently, in the English corpus as well, was rather low in comparison with the previously discussed high-frequency collocation patternings. In fact, a few instances of the following low-frequency collocations were found: noun + verb (6 out of 168 LC) (e.g.

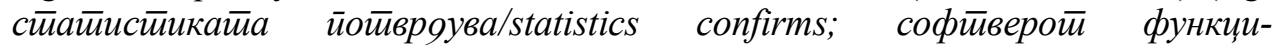
онира/software works; реакиија услеgu/reaction followed); verb + adverb (6 out of 168 LC) (е.g. насииайува заеgно/to run jointly; згоолемува иирикрайно/increases threefold; јасно заирйува/to set out clearly); adverb + adjective (8 out of 168 LC) (e.g. особено иноикаииивно/particularly indicative; целосно исиравна/completely justified); adjective + and + adjective (3 out of 186 LC) (e.g. безбеgна и

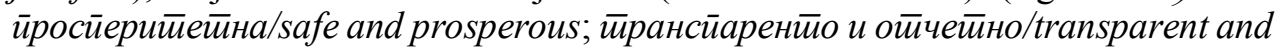
accountable) and noun + and + noun (4 out of 168 LC) (e.g. ycüecu $u$ üagови/successes and failures; pacī и paзвоj/growth and development). 


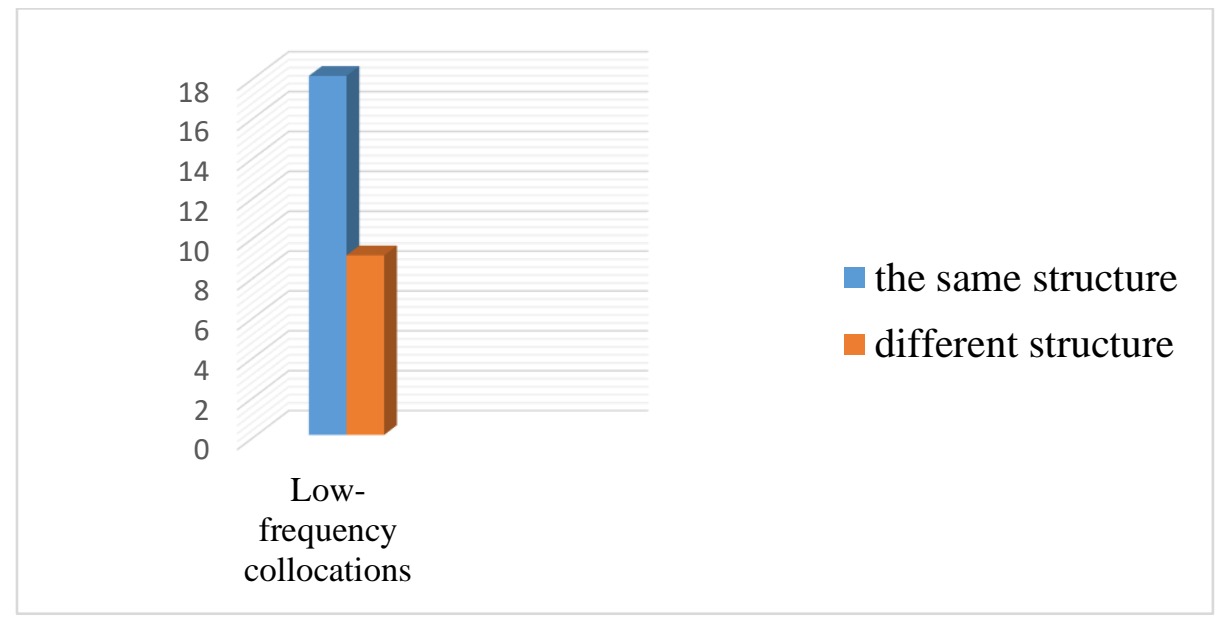

Figure 4. The structure of the low-frequency LC

As witnessed in the above-discussed examples, most of the translation equivalents in English of the low-frequency lexical collocations were also of the same type as their original counterparts (see Figure 4). Only an insignificant number of the translation equivalents in English had a different structure, i.e. were of a different subtype (5 out of 27 LC) (e.g. весницийе навеgуваай (noun + verb)/according to media (preposition + noun), ичелосно исиравно (adverb + adverb)/correct move (adjective + noun), etc.).

Finally, in the last phase of the research the translation strategies employed by the translators in rendering the analyzed LC from Macedonian into English were analysed. As stated previously, in most cases, not only were the source texts LC correctly translated in the TL but also they have identical syntactic structure with their counterparts in the target texts. This means that the predominant translation strategy employed in the analyzed corpus of journalistic texts was literal translation, i.e. word-for-word translation. This finding implies that literal translation proved to be a workable translation strategy in this type of technical translation. One possible explanation for the predominant usage of literal translation could be that the analysed journalistic texts referred to politics and politics-related issues, and, consequently, abounded with cross-linguistic LC. Considering the time constraint under which the translating of articles for daily newspapers takes place, the abundance of such cross-linguistic collocations, at the expense of culture-specific collocations, is a clear advantage and alleviating circumstance for the translators who deal with such texts.

Nonetheless, one should not lose sight of the fact that this same strategy, wordfor-word translation, instigated by a heavy mother tongue influence or interference, on the other hand, as mentioned previously, was also one of the reasons why the translators' solutions in the case of some LC backfired completely. A thorough analysis of these cases, actually, revealed that these mistranslated LC were not collocations typically used in the domain of political discourse; they were collocations pri- 
marily used in other registers (e.g. фабричка грешка/ manufacturing defect (industry), тектонски промени/tectonic shifts (geology), etc.), and in the analysed journalistic texts they were used with some kind of a figurative meaning.

Apart from the predominant translation strategy, the findings indicate that, although much less frequently, still, the translators resorted to using some of the other translation strategies as well (see Figure 5).

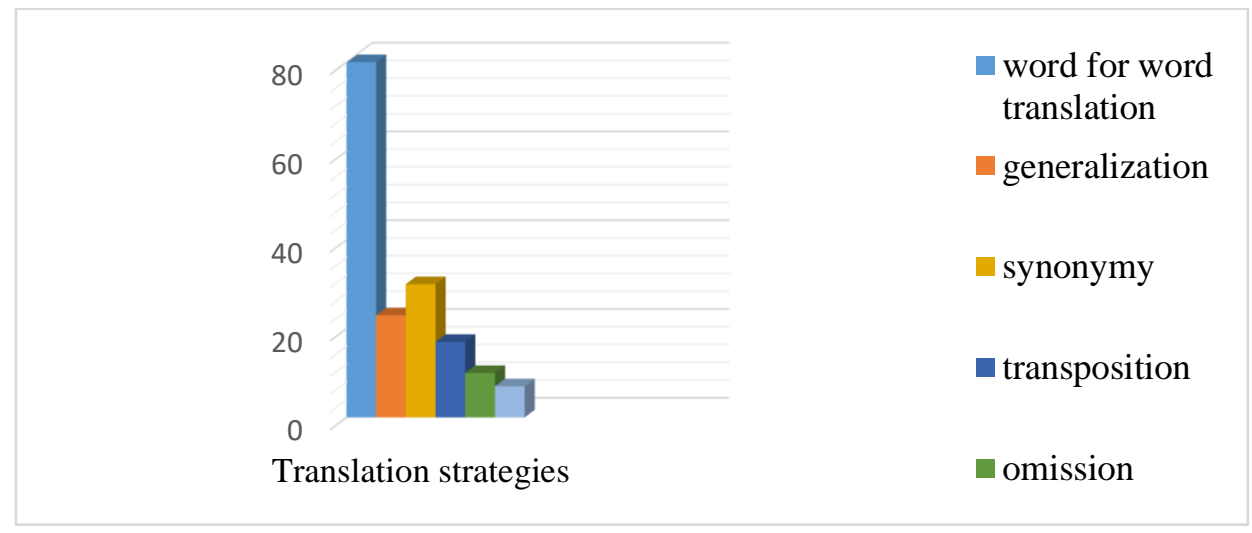

Figure 5. Translation strategies

This is in line with the fact that one smaller portion of the corpus of collocations were rendered in English as single words; some were not rendered at all, i.e. were omitted, and some had a syntactic structure different from the one of their counterparts in the original texts. More precisely, the findings point to the usage of the following translation strategies: generalization (using a more general/neutral term) (е.g. науминува ирроблемlto solve problems instead of overcome a problem), synonymy (е.g. мачни реформи/hard reforms instead of difficult reforms;

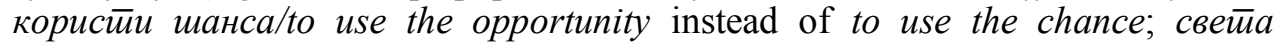
мuсuja/holy quest instead of holy mission); transposition (changes in the word class/order) (е.g. ирави гоолем ириоонес/to contribute to; зайочнува ирреговори/the start of negotiation); omission (е.g. иолиииччка сиена/political scene - the collocation was omitted in the transaltion), and modulation (е.g. лесна мобилизaunja/not difficult mobilization).

\section{Conclusion}

Generally speaking, the study showed that the level of awareness of translators when detecting and rendering lexical collocations in the TL was relatively high. In other words, the majority of the SL collocations were rendered correctly. An insignificant portion of them were either completely omitted or rendered as single words. Relatively few mistakes occurred in the translation, and these could be mainly attributed 
to word-for-word translation, false friends, overly free translation and atypical collocations in the original texts. Nevertheless, the overarching reason for these mistranslations can also be looked for in the time constraint under which the translation of journalistic texts is produced, and even perhaps the work load of translators on a daily basis, both of which seriously undermine the prospects for revision and correction of translated texts.

Furthermore, adjective + noun and verb + noun combinations were the two predominant types of lexical collocations both in the source and target texts. The category of the low-frequency lexical collocation was more varied and it included: noun + verb; adjective + adverb; adverb + verb; adjective + and + adjective and noun + of + noun collocations. On the basis of these findings, the overall conclusion is that despite the fact that the comparison was made between two completely different languages, Macedonian and English, still there was no difference in the frequency with which the various types of lexical collocations were used. Furthermore, no significant differences were found in the syntactic structure of the source collocations and their corresponding TL collocations.

Given that Macedonian and English are not related languages, the only viable explanation for the usage of the same types of LC and the great similarity in their syntactic structure is that the analysed collocations come from the domain of political discourse, and, consequently, the great majority of them, in fact, are cross-linguistic. In close correlation with the above discussed findings are the insights gained regarding the translation strategies employed in this context. Given that most of the source collocations had their counterparts in English with the same semantic content and syntactic structure, the most predominant translation strategy was literal or word-forword translation. In the cases when the target language collocations differed in type and syntactic structure from their source language counterparts, a range of other translation strategies were utilized (e.g. generalization, synonymy, transposition, modulation and omission).

One of the downsides of this study is that it investigated only politics-related journalistic texts, which means further studies are needed to inspect LC in other types of texts (e.g. literary texts). Also, the corpus was rather limited in size and the analysis was conducted manually. The subsequent studies should deal with this issue by including data form much larger electronic corpora and the analysis should be performed automatically.

\section{References}

Baker, M. (1992). In other words. London: Routledge.

Barnwell, K. (1980). Introduction to semantics and translation: with special reference to Bible translation ( $2^{\text {nd }}$ edn.). Horsleys Green: Summer Institute of Linguistics.

Benson, M., Benson E. and Ilson, R. (1986). The BBI combinatory dictionary of English: A guide to word combination. Amsterdam: John Benjamins. 
Benson, M., Benson E. and Ilson, R. (1997). The BBI dictionary of English word combinations. Amsterdam: Benjamins.

Hatim, B. and Mason, I. (1990). Discourse and the translator. London: Longman.

Hill, J. (2000). Revising priorities: From grammatical failure to collocational success. In M. Lewis (ed.), Teaching collocation: further development in the lexical approach. Oxford: Oxford University Press.

Mahdi, A. and Yasin, M. (2015). Translating Collocations from English to Arabic among Iraqi EFL learners. English Language and Literature Studies, 5(3): 57-65.

McIntosh, C., Francis, B. and Poole, R. (eds.). (2009). The Oxford collocations dictionary for students of English. Oxford: Oxford University Press.

Newmark, P. (1981). Approaches to Translation. Oxford: Pergamon.

Shammas, A. N. (2013). Collocation in English: comprehension and use by MA students at Arab universities. International Journal of Humanities and Social Science Vol. 3 No. 9: 107-122.

Shraideh, K. W. and Mahadin, R. S. (2015). Difficulties and strategies in translating collocations in BBC political texts. Arab World English Journal (AWEJ) Vol.6. No.3: 320-356.

Sinclair, J. (1991). Corpus, Concordance, Collocation. Oxford: Oxford University Press.

Vinay, J. P. and Darbelnet, J. (1995). Comparative stylistics of French and English: a methodology for translation (Vol. 11). Amsterdam/Philadelphia: John Benjamins Publishing.

Yamashita, J. and Jiang, N. (2010). L1 influence on the acquisition of L2 collocations: Japanese ESL users and EFL learners acquiring English collocations. TESOL Quarterly, 44: 647-668.

Lea, D. (ed.). (2002). Oxford Collocations Dictionary for Students of English. Oxford: Oxford University Press.

Јанушева, В. (2018). Аналитички прирок во новинарскиот потстил во македонскиот јазик. Mundo Eslavo, 17: 90-106.

Карапејовски, Б. (2011). За некои аспекти на глобализацијата и нејзиното влијание врз македонскиот јазичен систем. Филолошки сӣууии, 2: 239-248.

\section{Appendix}

\section{The newspaper articles excerpted from Nezavisen}

\begin{tabular}{|c|c|c|c|}
\hline & MC corpus & EN corpus & Date of release \\
\hline 1. & 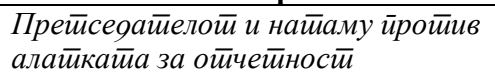 & $\begin{array}{l}\text { The President still against the } \\
\text { tool for accountability }\end{array}$ & 29.06 .2018 \\
\hline 2. & 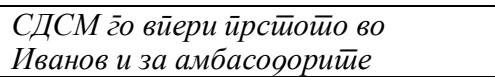 & $\begin{array}{l}\text { SDSM points its finger to Ivanov } \\
\text { concerning the Ambassadors }\end{array}$ & 29.06 .2018 \\
\hline 3. & Кој г̄о избра Иванов? & Who elected Ivanov? & 29.06 .2018 \\
\hline 4. & 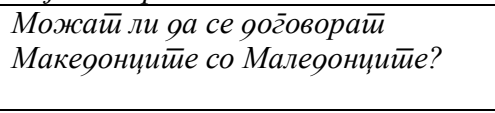 & $\begin{array}{l}\text { Can Macedonians come to an } \\
\text { agreement with the Macedoni- } \\
\text { ans? }\end{array}$ & 29.06 .2018 \\
\hline 5. & 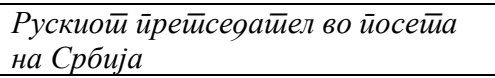 & $\begin{array}{l}\text { Russian President on an official } \\
\text { visit to Serbia }\end{array}$ & 02.07 .2018 \\
\hline 6. & $\begin{array}{l}\text { На Макеоонија и йреба нова } \\
\text { ирерооба }\end{array}$ & Macedonia needs a new revival & 02.07 .2018 \\
\hline 7. & Зоийо НАТО и ЕУ? & Why NATO and EU? & 02.07 .2018 \\
\hline
\end{tabular}

